This item was submitted to Loughborough's Research Repository by the author.

Items in Figshare are protected by copyright, with all rights reserved, unless otherwise indicated.

\title{
Urban Aquatic Ecosystems: the good, the bad and the ugly
}

PLEASE CITE THE PUBLISHED VERSION

http://dx.doi.org/10.1127/fal/2014/0716

\section{PUBLISHER}

(C) E. Schweizerbartsche Verlagsbuchhandlung

\section{VERSION}

SMUR (Submitted Manuscript Under Review)

\section{PUBLISHER STATEMENT}

This work is made available according to the conditions of the Creative Commons Attribution-NonCommercialNoDerivatives 4.0 International (CC BY-NC-ND 4.0) licence. Full details of this licence are available at: https://creativecommons.org/licenses/by-nc-nd/4.0/

\section{LICENCE}

CC BY-NC-ND 4.0

\section{REPOSITORY RECORD}

Moggridge, Helen L., Matthew J. Hill, and Paul J. Wood. 2019. "Urban Aquatic Ecosystems: The Good, the Bad and the Ugly". figshare. https://hdl.handle.net/2134/16644. 


\section{Urban Ecosystems: the good the bad and the ugly}

Moggridge, H.L. ${ }^{1}$, Hill, M.J. ${ }^{2}$ and Wood, P.J. ${ }^{2}$

1. Ecosystem Dynamics and Biogeochemistry Research Group, Department of Geography, University of Sheffield, Winter Street, Sheffield, S10 2TN, UK.

Email: h.l.moggridge@sheffield.ac.uk

2. Centre for Hydrological and Ecosystem Science, Department of Geography, Loughborough University, Loughborough, Leicestershire, LE11 3TU. UK Email: p.j.wood@Iboro.ac.uk

Author for Correspondence:

Helen L. Moggridge

Ecosystem Dynamics and Biogeochemistry Research Group

Department of Geography

University of Sheffield

Winter Street

Sheffield

S10 2TN

UK.

Email: h.l.moggridge@sheffield.ac.uk 
Urbanisation has had a profound impact on the natural environment (Pickett et al., 2001; Grimm et al., 2008), with a growing proportion of the global population living in urban areas (United Nations, 2010). Historically, urban centres were typically located close to waterbodies due to the ecosystem services that they provided to society including: water, food, power and transport (Everard and Moggridge, 2012; Chester and Robson, 2013). In contemporary towns and cities waterfronts remain the focus for many economic and recreational activities (Francis, 2012; Mansfield et al., This Volume) and have been the focal points for regeneration and restoration activities. Urban waterbodies have been subject to significant degradation as a result of urbanisation, leading to reductions in floral and faunal biodiversity and compromising their ability to deliver the services for which the original urban centre developed (Grimm et al., 2008).

Attitudes towards urban waterbodies are changing as part of wider reformation in the way in which the environment is viewed (Findlay and Taylor, 2006). Urban waterbodies are no longer simply viewed as degraded systems of little value, but as novel ecosystems with an intrinsic value in their own right (Francis, 2014; Moyle In Press), that make significant contributions to both local and regional biodiversity and conservation activities (Hassall, 2014; Kowarik, 2011). Despite extensive degradation, urban water bodies retain some functionality acting as natural retention (sediment or water) features (Briers, 2014), 'biohighways' (Francis, 2014) or refugia (Chester and Robson, 2013) in urban areas, and facilitating species migration and connectivity between isolated habitats and populations (Findlay and Taylor, 2006). The role of urban waterbodies in providing important regulating and cultural ecosystem services (in addition to the provisioning services identified above) is also increasingly recognised. For example, urban aquatic environments can provide psychological benefits, promoting reflection, relaxation, the feeling of freedom and even playing a spiritual role (Karmanov and Hamel, 2008; Voelker and Kistemann, 2013), in a comparable manner to green spaces (White et al., 2010). Consequently, there has been increased interest in restoring urban waterbodies, driven in part by legislation, such as the Water Framework Directive and Habitats 
Directive in Europe, the Clean Water Act in the US and policy frameworks in Australia (Findlay and Taylor, 2006). Concurrent with this increased interest in conservation and restoration, there has been an expansion in academic research on urban aquatic ecosystems, with publications on urban water bodies seeing a particularly marked increase over the past decade (e.g., Davies et al 2009; Everard and Moggridge2012; Francis, 2012; Gledhill and James, 2012). The papers included in this special issue of Fundamental and Applied Limnology comprises a cross-selection of the growing body of research on urban aquatic ecosystems encompassing both lentic and lotic ecosystems. The papers included herein form the output from a joint meeting of the British Hydrological Society and Royal Geographical Society Biogeography Research Group meeting, held at Loughborough University in April 2013 which attracted 20 oral and poster contributions and over 75 delegates.

\section{Ecosystem Responses to Urbanisation}

The impacts of urbanisation on river systems are well documented and there are a number of comprehensive review papers synthesising current knowledge (e.g. Paul and Meyer, 2001; Wenger et al., 2009; Francis, 2012). To date, this research been heavily biased towards studies from North America, Western Europe and Asia (mainly China) (Francis, 2012), despite the rapid urban growth in countries with emerging economies. Research has demonstrated changes to hydrology, geomorphology and water chemistry, which has had significant impacts on ecology. Hydrologically, it is well established that increases in impervious cover, coupled with drainage systems in urban areas, create a flashier hydrological regime; for example, a study of nine urban areas dispersed across the United States showed a consistent pattern of increased magnitude and frequency of high flow events associated with urbanisation (Brown et al., 2009). Whilst this trend is well documented in temperate regions, evidence from Puerto Rico, where rivers are naturally flashy due to the precipitation regime and catchment characteristics, indicated that urban river regimes did not differ from naturally forested catchments (Ramírez et al., 2009), highlighting the need for further research in other ecoregions (Hughes et al., 2014b). Urbanisation can also modify the hydrological regime at 
the other end of the continuum via a reduction in base flows (Wenger et al., 2009), aquatic connectivity (Kaushal and Belt, 2012), and sediment delivery and transport (Taylor and Owens, 2009) resulting in changes to channel morphology (Chin, 2007). Such geomorphological changes can be exacerbated by the extensive anthropogenic modifications that accompany urbanisation, including bank reinforcement, channel enlargement, planform alteration and the creation of in-channel barriers, resulting in simplified channels with reduced habitat diversity (Gurnell et al., 2007).

In addition to physical pressures, urban rivers are subject to changes in water chemistry, due to runoff from urbanised surfaces and from direct point source discharges. Consequently, many urban rivers have elevated nutrient, heavy metal, pesticide and other organic contaminant concentrations (Paul and Meyer, 2001; Gurnell et al., 2007; Lynch et al, 2014) and, significantly modified biogeochemical cycles (Kaushal and Belt, 2012). Rapid urbanisation in developing and emerging economies has caused marked declines in water quality, for example in Shanghai, China (Zhao et al., 2006; Wang et al., 2009). However, legislative controls, wastewater treatment and industrial decline have helped to improve urban river quality within cities in some highly developed regions such as the UK (e.g. the River Don, Sheffield, Maltby et al., 2010, the River Tame, Birmingham, UK, Langford et al., 2010), although the legacy of historic activities initiated during the industrial revolution, such as heavy metals (Lynch et al. 2014) and diffuse pollution inputs persist (Environment Agency, 2007). This combination of physical changes has resulted in well documented declines in biotic richness and changes in species composition in urban rivers, described as the "Urban Stream Syndrome" (Walsh et al., 2005).Whilst Wenger et al. (2009) suggest that responses to urbanization are reasonably consistent across different biogeoclimatic regions; studies have demonstrated differences according geographical area and initial assemblage composition (Brown et al. 2009; Ramírez et al., 2009).

In addition to the large number rivers and streams within urban landscapes, there are numerous lentic habitats and waterbodies (Hassall, 2014; Gaston 2005). It is important to recognise that the 
majority of lentic waterbodies in urban areas have been constructed (rather than being formed by natural processes). Lentic waterbodies have been built in urban areas for a variety of reasons including: aesthetic value (ornamental ponds and lakes located within urban parks and domestic gardens), to reduce flood risk and to store contaminants from urban runoff from urban streams and rivers (Williams et al., 2013; Briers, 2014). Urban wetlands are often created on wasteland or disused / redundant 'brown field' urban spaces. However, even though they are frequently small in size and many have developed with little consideration of their wider ecological or conservation value, they provide valuable habitats and refuges for a range of flora and fauna (Chester and Robson, 2013; Scheffers and Paszkowski, 2013), whilst also performing important ecosystem services such as carbon storage (Waletzko and Mitsch, 2013). Despite these benefits, lentic ecosystems within urban areas have historically been poorly studied and valued compared to their lotic counterparts.

The pressure associated with urbanization on lentic systems has stimulated research in a number of key areas. Lentic habitats have been shown to improve urban water quality and play a key role in bioremediation (Shutes, 2001). It is also clear that floral and faunal communities flourish within urban lentic waterbodies; although their ability to serve as refugia has not been fully realised. The multiple roles of lentic waterbodies increasingly recognised within urban areas (Briers, 2014).

\section{Restoration of Urban Aquatic Ecosystems}

There has been a marked increase in urban aquatic ecosystem restoration projects within recent years (Bernhardt et al., 2005; Chester and Robson, 2013; Mansfield et al., This Volume) and much debate as to what the objectives and outcomes of restoration activities should be. There has been a movement away from trying to re-create a pre-disturbance, reference state, as it is recognised that this is usually unfeasible and that many have been impacted by humans for so long that no true 'natural' analogues exist to serve as reference conditions (Dufour and Piegay, 2009; Moyle, In Press). Further, restoration to pre-disturbance conditions could negatively impact communities which have 
established in the new, altered state and which may have their own conservation value (Funk et al. 2013). Thus the goal of river restoration should not be to recreate unknown or unobtainable conditions, but to move the river towards the least degraded and most ecologically dynamic state possible (to include biology, hydrology and geomorphology) (Palmer et al., 2005). Others have advocated an ecosystem services approach that considers both the context of the system(s) along with the needs of society (Dufour and Piegay, 2009; Gilvear et al., 2013). Such debates are particularly pertinent in urban river systems, as there are conflicting social (including political), economic and environmental pressures associated with any decision (Findlay and Taylor, 2009) and any restoration measure have to work within the physical, chemical and social constraints of the urban environment. Thus, urban rivers are rarely (if ever) truly 'restored' (i.e. returned to a fully recovered natural ecosystem), but are instead 'rehabilitated' (i.e. where some, but not all, of the elements of the natural system are returned) or 'remediated' (i.e. improved, but without the intention to return to any pre-modified condition) (Findlay and Taylor, 2009).

Urban river restoration (used here in its broadest sense to incorporate any improvement) has been mostly opportunistic, focussing on small-scale habitat enhancements (Booth, 2005). Success of such schemes has been mixed (Cockerill and Anderson, 2014), as increased habitat heterogeneity does not necessarily promote biodiversity (Palmer et al., 2010), especially when wider pressures such as hydrological alteration and water pollution prevail (Hughes et al., 2014a). This reflects a wider lack of knowledge of process-based river restoration (Palmer et al., 2014), which is exacerbated by a profound lack of post-project monitoring. Although others have highlighted the need to focus on restoring physical and ecosystem processes rather than specific habitats, and stress the need to address catchment-scale issues, such as storm water management and water quality improvement, before rehabilitating physical habitat (Francis, 2014; Hughes et al. 2014a; Lake et al. 2007). 
A key element of any urban river restoration is the provision of benefits to society: "any small improvement in the ecological integrity of an urban stream will be beneficial because it will continue to provide, or even improve the social amenity as well as the ecosystem services that are essential to urban riparian corridors" (Findlay and Taylor, 2006, pg.317). However, these are not always complementary and an analysis of the impacts of increased floodplain connectivity in Vienna, Austria, demonstrated that proposed measures would provide ecological benefits, but with tradeoffs in ecosystem service provision (Sanon et al., 2012). Conversely, Cockerill and Anderson (2014) identified that stream restoration for societal benefits (aesthetics, erosion control, protection of infrastructure) provided little wider environmental benefit.

\section{Contributions and Future Research}

The papers in this special issue reflect the diversity of research currently being undertaken in both riverine and lentic urban aquatic ecosystems and address a range of fundamental research questions and taxonomic groups. The first four papers centre on lotic systems within the River Thames catchment, one of the most densely populated catchments in the UK. The first illustrates how attempts to physically restore and rehabilitate urban rivers may result in limited or no perceptible ecological benefit / enhancement. Examination of leaf litter decomposition rates and macroinvertebrate community composition of selected reaches of tributaries of the River Thames (UK) indicated that there were no significant differences between restored and unrestored sections (Smith and Chadwick, 2014). The second paper examines how ecological engineering techniques may be used to provide artificial surfaces for the enhancement of the species pool within the tidal reaches of the R. Thames (Hoggart and Francis, 2014). Coir rolls (processed coconut fibre) were used to trap macrophyte seeds on the hard engineered walls forming the banks of the river. Following exposure to the river, the rolls were used to determine the abundance, diversity and viability of macrophyte seeds transported and delivered to the walls. The results illustrate how novel ecosystem engineering techniques could be used to enhance the urban biodiversity in the future if incorporated 
into bank engineering structures appropriately. Robertson and others (2014) present the results of a long-term study examining the primary colonisation by invertebrates of the Jubilee River following its construction as a flood alleviation channel for the R. Thames. The results demonstrate that colonisation and succession of the invertebrate community was rapid following construction and that the abundance and diversity of taxa varied significantly over the study period (2001-2008), particularly following high flows. However, within a relatively short period of time the invertebrate community was distinct from the main $\mathrm{R}$. Thames, clearly illustrating how anthropogenic systems differ from those formed by natural processes. The last paper centres on the R. Thames catchment examines the status of barbell (Barbus barbus) in the lower River Lee associated with a pollution episode in 2006 (Ziębe et al., 2014). Long-term population data indicated a progressive decline in the abundance of fish from the 1970s through to 2009, and that the pollution incident may have onky served to exacerbate this process. Fish tagged to examine their movement patterns demonstrated very strong affinities to individual river reaches and a reluctance to leave their 'home' area despite increasing urbanisation and modification to the watercourse. The final lotic ecosystem contribution highlights the potential benefits of riparian vegetation buffer-zones on instream fish and macroinvertebrate communities in the R. Corgo (Portugal) (Coelho et al., 2014). The development of habitat suitability curves for native fish species demonstrates how the maintenance of riparian vegetation is important and that some urban stream sites may have a higher ecological status and habitat quality than agricultural reaches on the same river due to the preservation and conservation of the riparian vegetation corridor.

The remaining three papers in the special issue examine the ecology of predominately lentic waterbodies within urban areas. Cross and others (2014) examine the response of phytoplankton within flooded urban gravel-pits to hydrological extremes (flood and droughts). The results indicated that lakes with high connectivity to rivers and input of water from urban areas were more susceptible to ecological disruption from extreme events, but were potentially less susceptible to 
toxic cyanobacteria blooms, which occur more frequently in lakes isolated from the river and with higher retention times. The second lentic waterbody contribution documents the ecological effects and changes within Salford Quays on the Manchester Ship Canal associated with the redevelopment and restoration of the site (Mansfield et al., 2014). Long term-datasets (1985-2010) were used to document changes in phosphorous and chlorophyll-a. The study highlights many of the issues and challenges of managing urban waterbodies and how natural processes, biomaniputation and invasive taxa have all contributed to its current status. The final paper examines the biodiversity of macroinvertebrates within garden and field ponds along a rural-urban gradient (Hill and Wood, 2014). The majority of garden ponds supported low taxon richness compared to field ponds and those taxa recorded were largely a subset of those in the wider pondscape. However, the results demonstrate that despite the relatively limited faunal diversity recorded and reduced conservation value, garden ponds potentially serve as refugia for some faunal groups, such as Odonata, with highly mobile adults.

Whilst an understanding of ecosystem responses to urbanisation is reasonably well established, further research on the impacts of urbanisation on habitat connectivity is required (Hughes et al., 2014b). Existing research has also tended to focus on specific geographic areas / regions and on relatively small catchments or waterbodies. Future research should therefore seek to extend research effort into other ecoregions (Hughes et al., 2014b), consider larger systems (Francis, 2012) and a wider variety of waterbodies (Chester and Robson, 2013; Hassall, 2014) to facilitate further understanding. There is also a need for additional basic fundamental knowledge of urban aquatic ecology (Francis, 2014; Hassall, 2014), including food web shifts and species interactions in responses to urbanisation (Wenger et al. 2009). Significant knowledge gaps exist in urban aquatic habitat restoration and a better understanding of the outcomes of restoration measures based on detailed analysis of pre- and post- project data would greatly improve the wider take-up, application and acceptance of restoration practises for urban aquatic habitats. Priorities for aquatic habitat 
rehabilitation that combine natural processes and ecosystem services (e.g., Gilvear et al. 2013) will undoubtedly form the basis of future management of urban aquatic systems.

\section{Acknowledgements}

The authors gratefully acknowledge the support of the British Hydrological Society and the Royal Geographical Society Biogeography Research Group for their support in facilitating the Urban Aquatic Ecosystems meeting. We would also like to thank Prof Anne Robertson for the opportunity to prepare this special issue and the Centre for Hydrological and Ecosystem Science for hosting and sponsoring the meeting at Loughborough University. 


\section{References}

Bernhardt, E. S., Palmer, M. A., Allan, J. D., Alexander, G., Barnas, K., Brooks, S., Carr, J., Clayton, S., Dahm, C., Follstad-Shah, J., Galat, D., Gloss, S., Goodwin, P., Hart, D., Hassett, B., Jenkinson, R., Katz, S., Kondolf, G. M., Lake, P. S., Lave, R., Meyer, J. L., O'Donnell, T. K., Pagano, L., Powell, B. and Sudduth, E., 2005: Synthesizing U.S. River Restoration Efforts. Science 308: 636-63

Booth, D. B., 2005: Challenges and prospects for restoring urban streams: a perspective from the Pacific Northwest of North America. Journal of the North American Benthological Society 24: 724737.

Briers, R. A., 2014. Invertebrate communities and environmental conditions in a series of urban drainage ponds in Eastern Scotland: implications for biodiversity and conservation value of SUDS. Clean - Soil, Air, Water 42: 193-200

Brown, L. R., Cuffney, T. F., Coles, J. F., Fitzpatrick, F., McMahon, G., Steuer, J., Bell, A. H. and Jason, T. M., 2009: Urban streams across the USA: lessons learned from studies in 9 metropolitan areas. Journal of the North American Benthological Society 28: 1051-1069.

Chester. E.T. and Robson B.J., 2013: Anthropogenic refuges for freshwater biodiversity: Their ecological characteristics and management. Biological Conservation 166: 64-75.

Chin, A., 2007: Urban transformation of river landscapes in a global context. Geomorphology 79: 460-487

Cockerill, K. and Anderson, W. P., Jr., 2014: Creating false images: stream restoration in an urban setting(1). Journal of the American Water Resources Association 50: 468-482.

Coelho, D., Hughes, S.J., Varandas, S., and Cortes, R.M.V., 2014: Conservation benefits of riparian buffers in urban areas: the case of the Rio Corgo (north Portugal).

Cross, I.D., McGowan, S., Needham, T. and Pointer, C.M. , 2014: The effects of hydrological extremes on former gravel pity lake ecology: management implications.

Davies, Z. G., Fuller, R. A., Lorman, A., Irvine K. N., Sims, V. and Gaston, K. J., 2009: A national scale inventory of resource provision for biodiversity within domestic gardens. Biological Conservation 142: 761-771.

Dufour, S. and Piegay, H., 2009: From the myth of a lost paradise to targeted river restoration: forget natural references and focus on human benefits. River Research and Applications 25: 568-581.

Environment Agency, 2007: The unseen threat to water quality: diffuse pollution in England and Wales report. Environment Agency, Bristol.

Everard,M. and Moggridge, H.,2012: Rediscovering the value of urban rivers. Urban Ecosyst 15: 293314

Findlay, S. J. and Taylor, M. P., 2006: Why rehabilitate urban river systems? Area 38: 312-325.

Francis, R., 2012: Positioning urban rivers within urban ecology. Urban Ecosyst 15: 285-291.

Francis, R. 2014: Urban rivers: novel ecosystems, new challenges. WIREs Water 1: 19-29 
Funk, A., Gschoepf, C., Blaschke, A. P., Weigelhofer, G. and Reckendorfer, W., 2013: Ecological niche models for the evaluation of management options in an urban floodplain-conservation vs. restoration purposes. Environmental Science \& Policy 34: 79-91.

Gaston, K. J., Smith, R. M., Thompson, K. and Warren, P.H., 2005: Urban domestic gardens (II): experimental test of methods for increasing biodiversity. Biodiversity and Conservation 14: 395-413.

Gilvear, D. J., Spray, C. J. and Casas-Mulet, R., 2013: River rehabilitation for the delivery of multiple ecosystem services at the river network scale. Journal of Environmental Management 126: 30-43.

Gledhill, D.G. and James, P., 2012: Socio-economic variables as indicators of pond conservation value in an urban landscape. Urban Ecosystems 15: 849-861.

Grimm, N.B., Faeth, S.H., Golubiewski, N.E., Redman, C.L., Wu, J., Bai, X. and Briggs, J.M., 2008:

Global Change and the Ecology of Cities. Science 319: 756-760

Gurnell, A.M., Lee, M.T. and Souch, C., 2007: Urban rivers: hydrology, geomorphology, ecology and opportunities for change. Geography Compass 1: 1118-1137

Hassall, C. 2014. The ecology and biodiversity of urban ponds. Wiley Interdisciplinary Reviews: Water 1: $187-206$

Hill, M.J. and Wood, P.J., 2014: The macroinvertebrate biodiversity and conservation value of garden and field ponds along a rural-urban gradient.

\section{Hoggart, S.P.G. and Francis, R.A., 2014: Use of coir rolls for habitat enhancement of urban river walls.}

Hughes, R. M., Dunham, S., Maas-Hebner, K. G., Yeakley, J. A., Harte, M., Molina, N., Shock, C. C. and Kaczynski, V. W., 2014a: A Review of Urban Water Body Challenges and Approaches: (2) Mitigating Effects of Future Urbanization. Fisheries 39: 30-40.

Hughes, R. M., Dunham, S., Maas-Hebner, K. G., Yeakley, J. A., Schreck, C., Harte, M., Molina, N., Shock, C. C., Kaczynski, V. W. and Schaeffer, J., 2014b: A Review of Urban Water Body Challenges and Approaches: (1) Rehabilitation and Remediation. Fisheries 39: 18-29.

Karmanov, D. and Hamel, R., 2008: Assessing the restorative potential of contemporary urban environment(s): Beyond the nature versus urban dichotomy. Landscape and Urban Planning 86: 115125.

Kaushal, S. and Belt, K., 2012: The urban watershed continuum: evolving spatial and temporal dimensions. Urban Ecosyst 15: 409-435.

Kowarik, I., 2011: Novel urban ecosystems, biodiversity, and conservation. Environmental Pollution 159: 1974-1983.

Lake, P. S., Bond, N. and Reich, P., 2007: Linking ecological theory with stream restoration. Freshwater Biology 52: 597-615.

Langford, T.E.L., SHaw, P.J., Howard, S.R.,Ferguson, A.J.D., Ottewell, D. and Eley, R., 2010: Ecological recovery in a river polluted to its sources: the River Tame in the English Midlands. In Batty, L. C. and 
Hallberg, K. B. (eds.): Ecology of Industrial Pollution. Cambridge University Press, Cambridge.

Langhans, S. D., Hermoso, V., Linke, S., Bunn, S. E. and Possingham, H. P., 2014: Cost-effective river rehabilitation planning: Optimizing for morphological benefits at large spatial scales. Journal of Environmental Management 132: 296-303.

Lynch S. F. H., Batty, L. C. and Byrne, P., 2014. Environmental risk of metal mining contaminated river bank sediment at redox-transitional zones. Minerals 4: 52-73.

Maltby, L., Paetzold, A. and Warren, P., 2010: Sustaining industrial activity and ecological quality: the potential role of an ecosystem services approach. In Batty, L. C. and Hallberg, K. B. (eds.): Ecology of Industrial Pollution. Cambridge University Press, Cambridge

\section{Mansfield, R., Williams, A., Hendry, K. and White, K., 2014: Drivers of changes in a redeveloped} urban lake: long term trends in a simplified system.

Moyle, P.B., In Press. Novel aquatic ecosystems: the new reality for streams in California and others Mediterranean climate regions. River Research and Applications DOI: 10.1002/rra2709.

Palmer, M. A., Bernhardt, E. S., Allan, J. D., Lake, P. S., Alexander, G., Brooks, S., Carr, J., Clayton, S., Dahm, C. N., Shah, J. F., Galat, D. L., Loss, S. G., Goodwin, P., Hart, D. D., Hassett, B., Jenkinson, R., Kondolf, G. M., Lave, R., Meyer, J. L., O'Donnell, T. K., Pagano, L. and Sudduth, E., 2005: Standards for Ecologically Successful River Restoration. Journal of Applied Ecology 42: 208-217.

Palmer, M. A., Menninger, H. L. and Bernhardt, E., 2010: River restoration, habitat heterogeneity and biodiversity: a failure of theory or practice? Freshwater Biology 55: 205-22

Palmer, M. A., Filoso, S. and Fanelli, R. M., 2014: From ecosystems to ecosystem services: Stream restoration as ecological engineering. Ecological Engineering 65: 62-70.

Paul, M. and Meyer, J., 2001: Riverine ecosystems in an urban landscape. Annual Review of Ecology and Systematics 32: 333-365

Pickett, S. T. A., Cadenasso, M. L., Grove, J. M., Nilon, C. H., Pouyat, R. V., Zipperer, W. C. and Costanza, R., 2001: Urban ecological systems: Linking terrestrial ecological, physical, and socioeconomic components of metropolitan areas. Annual Review of Ecology and Systematics 32: 127-157.

Ramírez, A., Jesús-Crespo, R. D., Martinó-Cardona, D. M., Martínez-Rivera, N. and Burgos-Caraballo, S., 2009: Urban streams in Puerto Rico: what can we learn from the tropics? Journal of the North American Benthological Society 28: 1070-1079.

Robertson, A., Dineen, G., Baker, R., Hancock, B. and Shaw, P., 2014: Macroinvertebrate community colonisation and succession in a new urban river: lessons for restoration.

Sanon, S., Hein, T., Douven, W. and Winkler, P., 2012: Quantifying ecosystem service trade-offs: The case of an urban floodplain in Vienna, Austria. Journal of Environmental Management 111: 159-172.

Scheffers, B. R., and Paszkowski, C. A. 2013. Amphibian use of urban stormwater wetlands: The role of natural habitat features. Landscape and Urban Planning, 113, 139-149. 
Shutes, R. B. E. 2001. Artificial wetlands and water quality improvement. Environment international, 26,5, 441-447.

Smith, B. and Chadwick, M.A., 2014: Litter Decomposition in highly urbanized rivers: influence of restoration on ecosystem function.

Taylor, K. and Owens, P., 2009: Sediments in urban river basins: a review of sediment-contaminant dynamics in an environmental system conditioned by human activities. J Soils Sediments 9: 281-303.

Voelker, S. and Kistemann, T., 2013: Reprint of: "I'm always entirely happy when I'm here!" Urban blue enhancing human health and well-being in Cologne and Dusseldorf, Germany. Social Science \& Medicine 91: 141-152.

Waletzko, E. J., and Mitsch, W. J. 2013. Methane emissions from wetlands: An<i> in situ</i> side-byside comparison of two static accumulation chamber designs. Ecological Engineering. In Press

Walsh, C. J., Roy, A.H., Feminella, J.W., Cottingham, P.D., Groffman, P.M., Morgan, R.P., 2005: The urban stream syndrome: current knowledge and the search for a cure. Journal of the North American Benthological Society 24: 706-723.

Wang, J., Da, L., Song, K. and Li, B.-L., 2008: Temporal variations of surface water quality in urban, suburban and rural areas during rapid urbanization in Shanghai, China. Environmental Pollution 152: 387-393.

Wenger, S. J., Allison, H. R., Jackson, C. R., Bernhardt, E. S., Carter, T. L., Filoso, S., Gibson, C. A., Hession, W. C., Kaushal, S. S., Martí, E., Meyer, J. L., Palmer, M. A., Paul, M. J., Alison, H. P., Ramírez, A., Rosemond, A. D., Schofield, K. A., Sudduth, E. B. and Walsh, C. J., 2009: Twenty-six key research questions in urban stream ecology: an assessment of the state of the science. Journal of the North American Benthological Society 28: 1080-1098.

White, M., Smith, A., Humphryes, K., Pahl, S., Snelling, D. and Depledge, M., 2010: Blue space: The importance of water for preference, affect, and restorativeness ratings of natural and built scenes. Journal of Environmental Psychology 30: 482-493.

Williams, C. J., Frost, P. C. and Xenopoulos, M. 2013. Beyond best management practices: pelagic biogeochemical dynamics in urban stormwater ponds. Ecological Applications 23: 1384-1395

Zhao, S., Da, L., Tang, Z., Fang, H., Song, K. and Fang, J., 2006: Ecological consequences of rapid urban expansion: Shanghai, China. Frontiers in Ecology and the Environment 4: 341-346.

Zięba, G., Stakenas, S., Ives, M., Godard, M.J. Seymore, J., Carter, M.G. and Copp, G.H., 2014: Longterm decline of barbel Barbus barbus in the original course of the lower River Lee (England), with particular reference to the survival of tagged fish during a water pollution incident. 